\title{
The prognostic utility of ascites sodium level in cirrhotic patients
}

\author{
Sirozlu hastalarda asit sodyum seviyesinin prognostik kullanımı
}

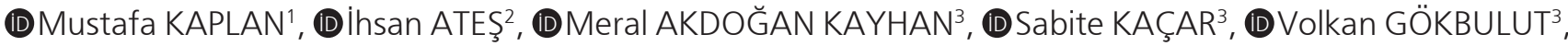 \\ (D) Orhan COŞKUN ${ }^{3}$
}

Department of 'Gastroenterology, Ahi Evran University Hospital, Kırşehir, Turkey

Departments of ${ }^{2}$ Internal Medicine and ${ }^{3}$ Gastroenterology, Ministry of Health Ankara City Hospital, Ankara, Turkey

\begin{abstract}
Background and Aims: In this study, we investigated the usefulness of the ascites sodium level for prognostic purposes and its association with 2-year mortality, spontaneous bacterial peritonitis, hepatic encephalopathy, and hepatorenal syndrome. Material and Methods: This study was performed between July and October 2018 in patients with liver cirrhosis in whom the ascites sodium level was studied. Patients with severe heart failure, nephrotic syndrome, or electrolyte disturbance; patients who had spontaneous bacterial peritonitis, hepatic encephalopathy or hepatorenal syndrome at admission; and patients who used diuretics for another reason were excluded from the study. Results: The study population consisted of 72 cirrhotic patients 32 females (44.4\%) and 40 males (55.6\%)]. The patients were followed up for 2 years, and mortality developed in 33 patients (45.8\%). During follow-up, hepatic encephalopathy developed in 13 patients (18.1\%), hepatorenal syndrome in 13 patients (18.1\%), and spontaneous bacterial peritonitis in 32 patients (44.4\%). Hepatic encephalopathy, hepatorenal syndrome, and the spontaneous bacterial peritonitis ratio were higher in the deep hyponatremia group compared with other hyponatremia groups $(p<0.05)$. The mean Child-Pugh and Model for End-Stage Liver Disease-Na scores were similar in the moderate and deep hyponatremia groups, and they were higher than in the other groups $(p<0.05)$. The mortality rate was found to be higher in the deep hyponatremia group than in the other hyponatremia groups $(p<0.05)$. Hyponatremia in ascites was found to be an independent predictor of mortality, and patients in the deep hyponatremia group had a 29.55-fold increased risk of mortality compared with those patients without hyponatremia. Conclusion: In this study, it was shown that deep hyponatremia less than $125 \mathrm{mEq} / \mathrm{L}$ in ascites was associated with increased cirrhotic complications and mortality.
\end{abstract}

Key words: Hyponatremia, hepatic encephalopathy, hepatorenal syndrome, spontaneous bacterial peritonitis

\section{INTRODUCTION}

Liver cirrhosis is a chronic disease with high mortality and morbidity. The most effective treatment of liver cirrhosis is liver transplantation (1). Scoring systems such as Model for End-Stage Liver Disease (MELD), MELD-sodium and Child-Pugh are used to determine the need for early transplantation in cirrhotic patients (2-4). In particular, hyponatremia included in the MELD-sodium score is an important predictor of prognosis (5-7). Hyponatremia is seen as a marker of early mortality and the risk of death increases with deepening hyponatremia (8). In additi-

Correspondence: Mustafa KAPLAN

Ahi Evran University, Department of Gastroenterology,

40100, Kırşehir, Turkey

Faks: +903863113958 • Email: mustafakaplandr@yahoo.com
Giriş ve Amaç: Bu çalışmada, asit sodyum düzeyinin prognostik amaçlarla kullanılabilirliği ve iki yıllık mortalite, spontan bakteriyel peritonit, hepatik ensefalopati ve hepatorenal sendrom ile ilişkisi araştırıldı. Gereç ve Yöntem: Bu çalışma Temmuz ve Ekim 2018 tarihleri arasında karaciğer sirozu olup asit sodyum düzeyi çalışılan hastalarla yapıldı. Şiddetli kalp yetmezliği, nefrotik sendrom veya elektrolit bozukluğu olan hastalar; başvuru sırasında spontan bakteriyel peritonit, hepatik ensefalopati veya hepatorenal sendromu olan hastalar ve başka bir nedenden ötürü diüretik kullanan hastalar çalışma dışı bırakıldı. Bulgular: Çalışma 72 sirotik hasta ile yapıldı [32 kadın (\%44.4) ve 40 erkek (\%55.6)]. Hastalar iki yıl boyunca takip edildi ve 33 hastada mortalite gelişti (\%45.8). 13 hastada hepatik ensefalopati (\%18.1), 13 hastada hepatorenal sendrom (\%18.1) ve 32 hastada spontan bakteriyel peritonit (\%44.4) gelişti. Hepatik ensefalopati, hepatorenal sendrom ve spontan bakteriyel peritonit gelişme oranı derin hiponatremi grubunda diğer hiponatremi gruplarına göre daha yüksekti $(p<0.05)$. Ortalama Child-Pugh ve Model for End-Stage Liver Disease-Na skorları orta ve derin hiponatremi gruplarında diğer gruplara göre daha yüksekti ( $p<0.05)$. Asit sıvısında hiponatremi mortalite için bağımsız bir prediktör olarak bulundu ve mortalite riski derin hiponatremisi olan hastalarda hiponatremi olmayan hastalara göre 29.55 kat daha fazla bulundu. Sonuç: Bu çalışmada asit sıvısında $125 \mathrm{mEq} / \mathrm{L}^{\prime}$ den daha düşük sodyum düzeyi ile artmış sirotik komplikasyonlar ve mortalite arasında ilişki olduğu gösterilmiştir.

Anahtar kelimeler: Hiponatremi, hepatik ensefalopati, hepatorenal sendrom, spontan bakteriyel peritonit

on, hyponatremia is associated with an increased risk of ascites, spontaneous bacterial peritonitis (SBP), hepatic encephalopathy (HES) and hepatorenal syndrome (HRS). (9). For hyponatremia, a limit of $130 \mathrm{mEq} / \mathrm{L}$ is generally taken as basis and almost one fifth of decompensated cirrhosis patients have hyponatremia (10).

Ascites is the most common complication of cirrhosis. The development of ascites in cirrhotic patients is considered as a decompensation finding and 5-year mortality

Kaplan M, Ateş I, Kayhan Akdoğan $M$, et al. The prognostic utility of ascites sodium level in cirrhotic patients. The Turkish Journal of Academic Gastroenterology 2021;20:87-93. DOI: 10.17941/agd.977865

Manuscript Received: 10.12.2020 • Accepted: 25.01.2021 
is $50 \%$ in patients with ascites (11). Although ascites itself is an important prognostic marker for cirrhosis, the parameters studied in ascites fluid are used for diagnostic purposes rather than prognostic purposes (12). In our literature review, there is no study investigating that ascites sodium level can be used for prognostic purposes. Therefore, in this study, we investigated the usefulness of ascites sodium level for prognostic purposes and its relationship with two-years mortality, SBP, HES and HRS.

\section{MATERIALS and METHODS}

This study was conducted on 72 patients with liver cirrhosis who had ascites sampling was done between July and October 2018. Etiological factors of the liver cirrhosis were recorded from patient files. Patients under 18 years of age, patients with incomplete files, severe heart failure, nephrotic syndrome or electrolyte disorder; patients with complications such as HES, HRS and SBP at admission and patients using diuretics for any other reason during the application were excluded from the study. Patients who were sampled of ascites for any other reasons at the time of admission (to investigate infection or acid etiology) and whose ascites sodium level had been studied were included in this study.

Hemoglobin, white blood cell count (WBC), platelet, international normalized ratio (INR), albumin, creatinine, sodium and potassium values were obtained from patient files. Child-Pugh, MELD and MELD-Na scores were calculated at admission. Complications were evaluated with 6-month follow-up. Those who were followed for less than six months were excluded from the study.

For HES, the hepatic encephalopathy scoring algorithm (HESA) score that recommended by 'International Hepatic Encephalopathy and Nitrogen Metabolism Consensus Association' was used (13). The diagnosis of SBP was based on a neutrophil [polymorphonuclear leukocyte (PMNL)] number greater than $250 / \mathrm{mm} 3$ in the ascitic fluid (14). HRS was diagnosed with using actual criterias after exclusion of secondary causes (15). Mortality during the follow-up period was recorded by using national databases. Patients were evaluated according to ascites sodium levels in four groups: no hyponatremia (> $135 \mathrm{mEq} / \mathrm{L}$ ), mild hyponatremia (130-134 mEq/L), moderate hyponatremia (125-129 mEq/L), and deep hyponatremia (<125 mEq/L).

Statistical analysis was performed using Statistical Package for Social Sciences (SPSS) for Windows 20 (IBM SPSS Inc., Chicago, IL) and Medcalc 11.4.2 (MedCalc Software, Mariakerke, Belgium). The normal distribution of the data was evaluated by Kolmogorov Smirnov test. Numerical variables with normal distribution were shown as mean \pm standard deviation, and numerical variables without normal distribution were shown as median (minmax). Categorical variables were expressed as numbers and percentages. The comparison of numerical variables between hyponatremia patient groups was evaluated by ANOVA (in the normal distribution numerical variables) and Kruskal Wallis $\mathrm{H}$ test (in the non-normally distributed numerical variables). Bonferroni correction was used as posthoc analysis. Chi-square and Fisher's exact chi-square test were used to compare categorical data. Multivariable Cox regression analysis was used to determine possible risk factors predicting mortality. Kaplan-Meier analysis was used for survival. Diagnostic performance assessment of possible risk factors for predicting mortality was performed by ROC Curve analysis. $\mathrm{P}<0.05$ was accepted as statistically significant.

This study was designed in accordance with the 2013 Brazilian version of the Helsinki Declaration and approved by the Ethics Committee and Research Committee of our hospital (Ministry of Health, Ankara Yüksek Ihtisas Hospital; 22.02.2018/34). Written consent was obtained from all participants who included in the study.

\section{RESULTS}

The study population consisted of 72 cirrhotic patients [32 female (44.4\%) and 40 male (55.6\%)]. The mean age of the patients was $58.8 \pm 14.3$ years. Thirty-eight patients had cryptogenic cirrhosis (52.8\%), 16 had cirrhosis due to hepatitis B (22.2\%), and 6 had alcoholic cirrhosis (8.3\%). The patients were followed up for 2 years and 33 patients died (45.8\%). During follow up, HES developed in 13 patients (18.1\%), HRS in 13 patients (18.1\%), and SBP in 32 patients (44.4\%). The mean Child-Pugh score was $9.5 \pm$ 1.8 (range: 6-13), the median MELD score was 14.5 (range: 6-40), and the median MELD-Na score was 21 (range: 6-40). It was revealed that 29 patients did not have hyponatremia $(40.3 \%), 16$ patients had mild hyponatremia $(22.2 \%), 17$ patients had moderate hyponatremia (23.6\%) and 10 patients had deep hyponatremia (13.9\%).

The clinical findings of the patients according to hyponatremia groups are shown in Table 1. According to this; age, sex and ascites etiology did not differ significantly between hyponatremia groups. The rate of HES, HRS and SBP was higher in deep hyponatremia group compared to other hyponatremia groups $(p<0.05)$. The mean Child-Pugh and the median MELD-Na scores were similar in the moderate and deep hyponatremia groups and were higher than other groups $(p<0.05)$. Mortality rate was higher in patients with deep hyponatremia compared to other hyponatremia groups $(p<0.05)$ and median survival time was low in these patients $(p<0.05)$. 
Table 1. Distribution of demographic and clinical characteristics by hyponatremia groups

\begin{tabular}{|c|c|c|c|c|c|}
\hline \multirow[b]{2}{*}{ Variables } & \multicolumn{4}{|c|}{ Hyponatremia in Ascites } & \multirow[b]{2}{*}{ p } \\
\hline & $\begin{array}{c}\text { None } \\
(>135) \\
n=29\end{array}$ & $\begin{array}{c}\text { Mild } \\
(130-135) \\
n=16\end{array}$ & $\begin{array}{c}\text { Moderate } \\
\begin{array}{c}(125-129) \\
n=17\end{array}\end{array}$ & $\begin{array}{c}\text { Deep } \\
(<125) \\
n=10\end{array}$ & \\
\hline Age & $63.2 \pm 14.8$ & $60.0 \pm 18.0$ & $54.3 \pm 8.4$ & $51.6 \pm 9.6$ & 0.064 \\
\hline \multicolumn{6}{|l|}{ Sex } \\
\hline Female & $11(37.9)$ & $8(50.0)$ & $8(47.1)$ & $5(50.0)$ & 0.850 \\
\hline Male & $18(62.1)$ & $8(50.0)$ & $9(52.9)$ & $5(50.0)$ & \\
\hline \multicolumn{6}{|l|}{ Ascites etiology } \\
\hline Cryptogenic & $18(62.1)$ & $8(50.0)$ & $7(41.2)$ & $5(50.0)$ & 0.124 \\
\hline Hepatitis B & $6(20.7)$ & $5(31.3)$ & $3(17.6)$ & $2(20.0)$ & \\
\hline Hepatitis C & $2(6.9)$ & - & - & - & \\
\hline Alcoholic & $2(6.9)$ & - & $3(17.6)$ & $1(10.0)$ & \\
\hline BCS & $1(3.4)$ & $1(6.3)$ & - & - & \\
\hline Veno-occlusive disease & - & - & $4(23.5)$ & $2(20.0)$ & \\
\hline Biliary cirrhosis & - & $1(6.3)$ & - & - & \\
\hline Cirrhosis due to NASH & - & $1(6.3)$ & - & - & \\
\hline HES & $3(10.3)$ & $1(6.2)$ & $3(17.6)$ & $6(60.0)$ & $0.004^{*}$ \\
\hline HRS & $4(13.8)$ & $1(6.3)$ & $2(11.8)$ & $6(60.0)$ & $0.006^{\star}$ \\
\hline SBP & $8(27.6)$ & $5(31.3)$ & $11(64.7)$ & $8(80.0)$ & $0.006^{\star}$ \\
\hline Child-Pugh score & $8.9 \pm 1.7^{c d}$ & $9.2 \pm 1.8^{\mathrm{cd}}$ & $10.4 \pm 1.8^{a b}$ & $10.3 \pm 1.8^{\mathrm{ab}}$ & $0.042^{*}$ \\
\hline MELD score & $14(8-40)$ & $15(6-31)$ & $26(9-31)$ & $18.5(13-40)$ & 0.217 \\
\hline MELD-Na score & $15(6-40)^{c d}$ & $19(9-34)^{c d}$ & $28(19-34)^{a b}$ & $25.5(18-40)^{\mathrm{ab}}$ & $<0.001^{*}$ \\
\hline Hemoglobin & $10.2 \pm 1.9$ & $11.5 \pm 2.1$ & $10.3 \pm 1.5$ & $11.7 \pm 3.1$ & 0.099 \\
\hline Platelets & $105(26-421)$ & $113(35-456)$ & $152(47-469)$ & $116(27-146)$ & 0.453 \\
\hline INR & $1.4(1-4.1)$ & $1.5(1-4)$ & $1.5(1-3.4)$ & $1.6(1.2-2.8)$ & 0.487 \\
\hline Creatinine & $1(0.4-4.3)$ & $1(0.5-5.6)$ & $1.3(0.7-2.5)$ & $1.2(0.6-2.7)$ & 0.326 \\
\hline Albumin & $2.5 \pm 0.6$ & $2.7 \pm 0.8$ & $2.2 \pm 0.7$ & $2.7 \pm 0.7$ & 0.106 \\
\hline Potassium & $4.3 \pm 0.6$ & $4.2 \pm 0.7$ & $4.6 \pm 0.5$ & $4.1 \pm 1.0$ & 0.133 \\
\hline Sodium & $137.3 \pm 4.0^{\mathrm{bcd}}$ & $132.6 \pm 3.4^{\mathrm{acd}}$ & $128.6 \pm 3.3^{\mathrm{abd}}$ & $120.1 \pm 3.3^{a b c}$ & $<0.001^{*}$ \\
\hline Ascites sodium & $140.6 \pm 3.7^{\mathrm{bcd}}$ & $132.6 \pm 2.1^{\mathrm{acd}}$ & $125.5 \pm 3.3^{\mathrm{abd}}$ & $111.5 \pm 5.4^{\mathrm{abc}}$ & $<0.001^{*}$ \\
\hline Ascites WBC $\left(\times 10^{3}\right)$ & $300(100-900)$ & $400(100-900)$ & $300(110-720)$ & $350(200-700)$ & 0.450 \\
\hline Ascites neutrophils & $200(100-790)$ & $200(100-700)$ & $400(100-630)$ & $200(100-500)$ & 0.231 \\
\hline Ascites glucose & $118(86-265)$ & $139(67-234)$ & $120(29-145)$ & $151.5(85-301)^{\mathrm{abc}}$ & $0.031 *$ \\
\hline Ascites albumin & $0.5(0.1-2)$ & $0.7(0.1-3.2)$ & $0.8(0.1-1.5)$ & $0.4(0.2-2.4)$ & 0.691 \\
\hline Mortality & $5(17.2)$ & $8(50.0)$ & $10(58.8)$ & $10(100.0)$ & $<0.001^{*}$ \\
\hline Follow-up & $22.8 \pm 3.8^{d}$ & $20.4 \pm 4.2^{d}$ & $18.6 \pm 5.5^{d}$ & $10.2 \pm 2.2^{\mathrm{abc}}$ & $<0.001^{*}$ \\
\hline
\end{tabular}

BCS: Budd-Chiari Syndrome, NASH: Non-alcoholic steatohepatitis, HES: Hepatic encephalopathy, HRS: Hepatorenal syndrome, SBP: Spontaneous bacterial peritonitis, INR: International normalized ratio, WBC: White blood cell count.

Numerical variables showing normal distribution were shown as mean \pm standard deviation. Numerical variables without normal distribution were shown as median (min-max). Categorical variables were expressed as numbers (\%).

a: $p<0.05$ vs hyponatremia (bonferroni adjusted)

b: $p<0.05$ vs hyponatremia (bonferroni adjusted)

c: $p<0.05$ vs hyponatremia (bonferroni adjusted)

$d: p<0.05$ vs hyponatremia (bonferroni adjusted)

$* p<0.05$ 
During 2-years follow-up, survival-related findings of cirrhotic patients are shown in Table 2. Accordingly, possible risk factors are: presence of HES, presence of HRS, presence of SBP, increased Child-Pugh score, increased MELD score, increased MELD-Na score, increased creatinine level, low sodium level, low ascites sodium level, presence of mild ascites hyponatremia, presence of moderate ascites hyponatremia and presence of deep ascites hyponatremia.

In the multivariable Cox regression model, where possible risk factors were included presence of HRS (HR: 6.36; $p<0.001$ ), presence of mild ascites hyponatremia (HR: 3.58; $p=0.025)$, presence of moderate ascites hyponatremia (HR: $5.93 ; p=0.001$ ) and presence of deep ascites hyponatremia (HR: 29.55; $p<0.001$ ) were found as independent predictors of mortality. Patients with mild hyponatremia had a 3.58-fold mortality risk compared to those without hyponatremia, patients with moderate hyponatremia had a 5.93-fold mortality risk compared to those without hyponatremia, patients with deep hyponatremia had a 29.55-fold mortality risk compared to those without hyponatremia (Figure 1).

\section{Table 2. Survival-related findings in two-year follow-up in cirrhosis patients}

\begin{tabular}{|c|c|c|c|c|}
\hline \multirow{2}{*}{ Variables } & \multicolumn{2}{|c|}{ Univariable } & \multicolumn{2}{|c|}{ Multivariable } \\
\hline & HR (95 Cl) & $\mathbf{p}$ & HR (95 Cl) & $\mathbf{p}$ \\
\hline Age & $0.98(0.96-1.01)$ & 0.985 & - & - \\
\hline \multicolumn{5}{|l|}{ Sex } \\
\hline Female & ref & & & \\
\hline Male & $1.61(0.78-3.31)$ & 0.200 & - & - \\
\hline HES & $6.05(2.96-12.33)$ & $<0.001 *$ & - & - \\
\hline HRS & $5.90(2.90-12.01)$ & $<0.001 *$ & $6.36(2.86-14.13)$ & $<0.001$ * \\
\hline SBP & $2.31(1.15-4.61)$ & $0.018^{*}$ & - & - \\
\hline Child-Pugh & $1.34(1.10-1.62)$ & $0.003^{*}$ & - & - \\
\hline MELD & $1.05(1.01-1.09)$ & $0.006^{\star}$ & - & - \\
\hline MELD-Na & $1.07(1.03-1.12)$ & $<0.001 *$ & - & - \\
\hline Hemoglobin & $1.10(0.94-1.30)$ & 0.240 & - & - \\
\hline Platelets & $1.00(0.99-1.01)$ & 0.934 & - & - \\
\hline INR & $1.37(0.94-1.99)$ & 0.104 & - & - \\
\hline Creatinine & $1.35(1.05-1.73)$ & $0.020^{*}$ & - & - \\
\hline Albumin & $0.82(0.47-1.42)$ & 0.466 & - & - \\
\hline Potassium & $0.83(0.48-1.44)$ & 0.509 & - & - \\
\hline Sodium & $0.83(0.78-0.89)$ & $<0.001^{*}$ & - & - \\
\hline Ascites sodium & $0.90(0.87-0.93)$ & $<0.001 *$ & - & - \\
\hline None & ref & & ref & \\
\hline Mild & $3.20(1.05-9.80)$ & $0.041 *$ & 3.58 (1.17-10.97) & $0.025^{*}$ \\
\hline Moderate & $4.65(1.06-13.66)$ & $0.005^{\star}$ & $5.93(1.98-17.80)$ & $0.001^{*}$ \\
\hline Deep & $30.03(9.82-91.82)$ & $<0.001 *$ & 29.55 (8.93-97.81) & $<0.001^{*}$ \\
\hline Ascites WBC & $1.00(0.99-1.00)$ & 0.373 & - & - \\
\hline Ascites neutrophils & $1.00(0.99-1.00)$ & 0.441 & - & - \\
\hline Ascites glucose & $0.99(0.99-1.01)$ & 0.542 & - & - \\
\hline Ascites albumin & $1.12(0.63-1.98)$ & 0.710 & - & - \\
\hline
\end{tabular}

HES: Hepatic encephalopathy, HRS: Hepatorenal syndrome, SBP: Spontaneous bacterial peritonitis, INR: International normalized ratio, WBC: White blood cell count. HR: Hazard ratio, Cl: Confidence interval, Ref: referance, , ${ }^{*} p<0,05$ 


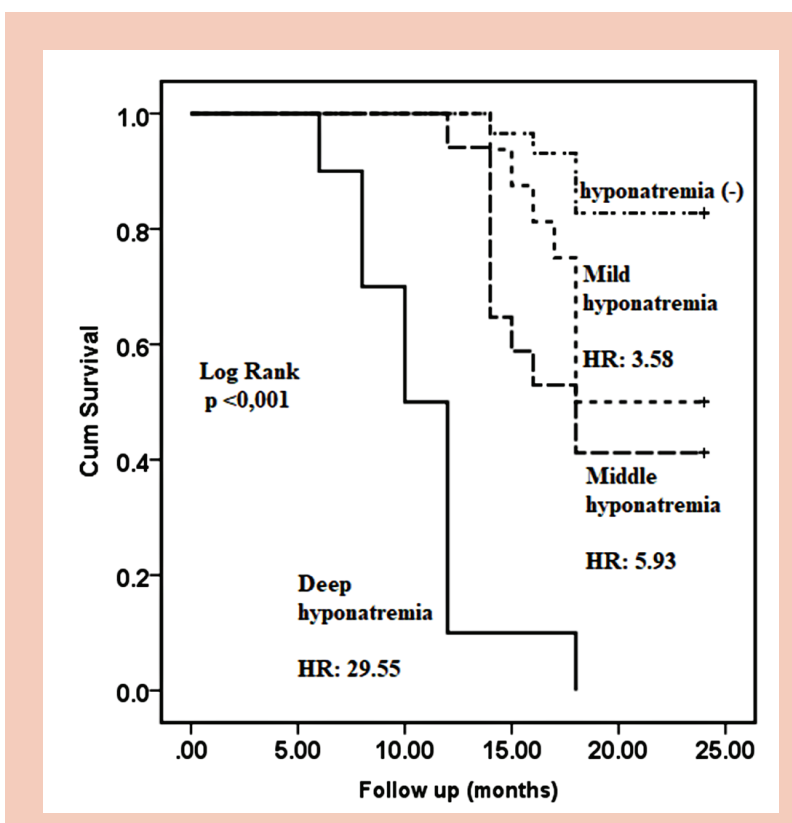

Figure 1. Multivariable Cox regression model that possible risk factors were included.

The diagnostic performance of possible risk factors for predicting mortality is shown in Figure 2. According to this; ascites hyponatremia risk factor showed superior performance compared to SBP risk factor for predicting mortality, but it did not show superiority compared to HES, HRS, MELD and MELD-Na risk factors.

\section{DISCUSSION}

This study was the first to investigate the prognostic significance of ascites sodium level, and it was shown that deep hyponatremia of less than $125 \mathrm{mEq} / \mathrm{L}$ in ascites was associated with increased cirrhotic complications and mortality.

In our study, it was shown that as ascites sodium decreased, complications such as HES, HRS and SBP, which are direct determinants of the prognosis of cirrhosis, increased. As it is known, HES is associated with increased hospitalization, hospital costs and mortality (16). Bustamante et al. revealed that 1-year life expectancy in cirrhotic patients with HES was $42 \%$ and 3-year life expectancy was only $23 \%(17)$. There are many factors that precipitate the development of HES. In one study, it was reported that hyponatremia exacerbated HES by increasing brain edema and that hyponatremia should be treated in the treatment of HES (18). There are no studies in the literature that correlate the ascites sodium level with HES. However, in our study, the risk of HES development

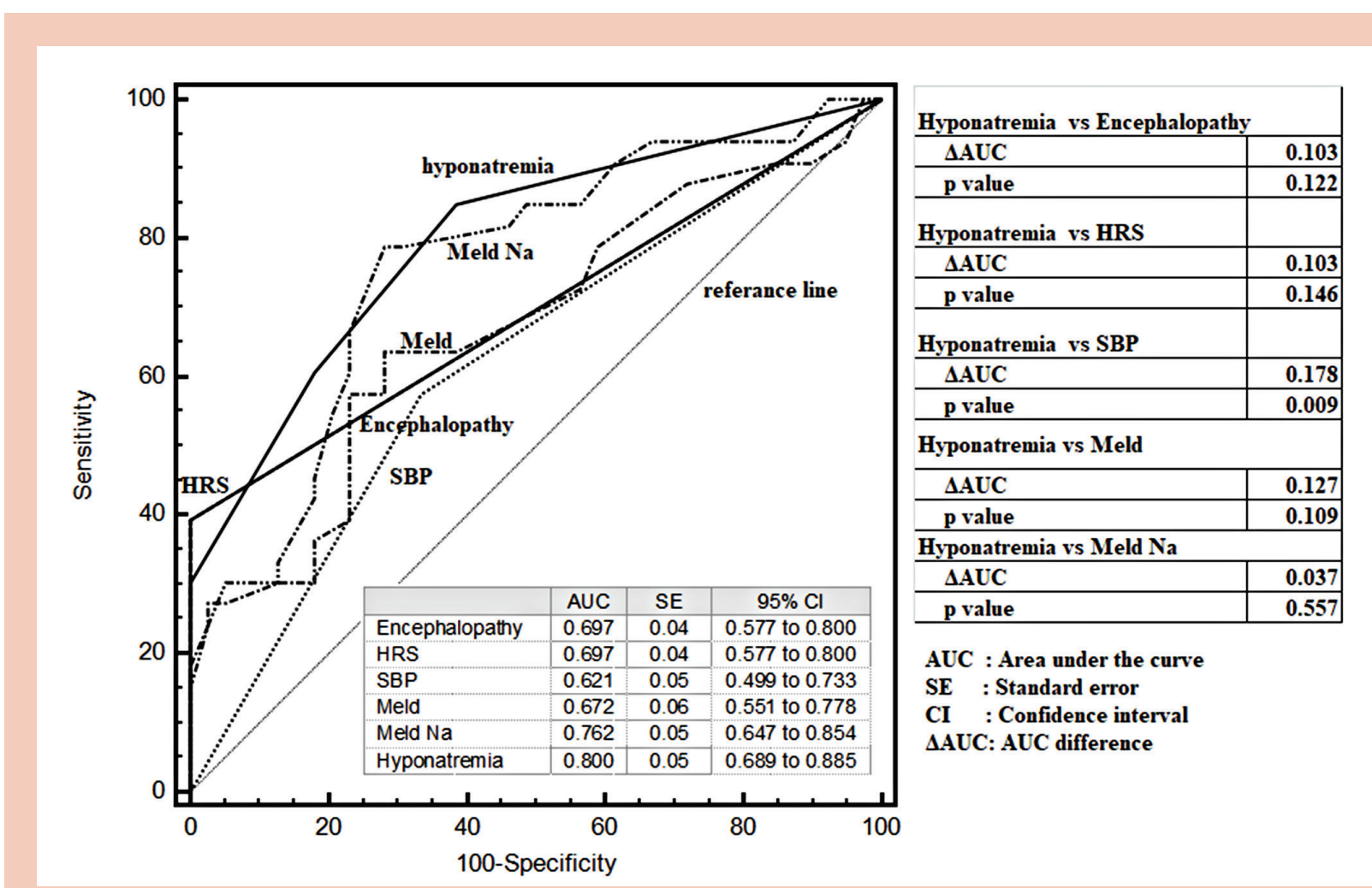

Figure 2. The diagnostic performance of possible risk factors for predicting mortality. 
in the follow-up was at most $20 \%$ in the no hyponatremia, mild or moderate hyponatremia groups, while this rate increased to $60 \%$ in the deep hyponatremia group. Although hyponatremia in ascites is an independent predictor of mortality, it is seen that hyponatremia in ascites has a higher AUC value compared to HES in ROC-curve analysis when independent predictors of mortality are compared.

Similarly, HRS and SBP are closely related to mortality in cirrhotic patients. In particular, the development of HRS is an important factor for short-term mortality (19). Portal hypertension and related systemic vasodilatation lead to activation of sodium-retaining neurohumoral mechanisms involving the renin-angiotensin-aldosterone system, the sympathetic nervous system, and antidiuretic hormone (ADH). Ascites is formed by retention of sodium and water to compensate for the low effective circulation volume. In late stages of cirrhosis, hyponatremia occurs with excess water retention. With the development of hyponatremia, the development of hepatorenal syndrome is accelerated (8). This relationship is seen more clearly in our study. As a matter of fact, HRS is seen significantly more in the presence of deep hyponatremia in the ascites.

In our study, SBP is seen more frequently seen in deep hyponatremia group than other groups. One reason for this may be that patients in this group have a worse prognosis. As a matter of fact, previous studies showed that the prevalence of SBP increases as the stage of cirrhosis increases (20). Another possible reason may be that the low ascites sodium level causes more susceptibility to infection as it disrupts blood electrolyte and pressure balance.

In our study, the presence of hyponatremia in ascites was correlated with MELD-Na score. As the hyponatremia deepens in the ascites, the patients' MELD-Na score increases. As it is known, MELD-Na score is a very important current score used to determine the need for transplantation (21). Considering this close relationship in our study, we think that hyponatremia in ascites may also be used for prognostic purposes such as hyponatremia included in the MELD-Na score, and perhaps a new score may be developed to determine the need for transplantation and complications, including ascites sodium level.

In our literature review, sampling of ascites is generally used for diagnostic purposes in patients with decompensated cirrhosis. Most parameters, especially ascites neutrophil and albumin, are used to determine the complica- tions of cirrhosis or to classify ascites $(22,23)$. As in our study, many parameters have been studied for determination of prognosis $(24,25)$, but there are not many studies done especially with blood electrolytes. Therefore, we believe that our study gives a new dimension to the approach to patients with ascites.

When independent risk factors for mortality were compared, the presence of hyponatremia in ascites outweighed only SBP. However, ROC-Curve analysis showed higher AUC values compared to other parameters. We think that hyponatremia in ascites is useful for early prognosis because of the need for detailed clinical and laboratory investigations for the determination of HES, HRS and SBP, but the ascites sodium value can be easily measured. Also in our study, ascites sodium level is looked before the other complications or mortality developed and this condition supports the idea of being an early parameter for prognosis determination.

Because serum hyponatremia often appears in advanced stages of cirrhosis, treatment is often too late. Since the serum sodium level of some of the patients with deep hyponatremia in ascites is still within normal limits, it suggests that the ascites sodium level may be an earlier prognostic marker than the serum sodium level.

The most important limitation of our study was the small number of patients. However, the presence of 72 cirrhosis patients with almost any etiology is considered sufficient for statistical analysis. Another important limitation is that some important complications such as hepatocellular carcinomas (HCC) are not included in the study analysis. However, the inclusion of major complications of cirrhosis such as HES, HRS and SBP in the analysis and comparing it with mortality, strengthens our study.

In conclusion, the presence of hyponatremia in ascites is an important predictor of mortality and cirrhosis complications and this relationship becomes more pronounced as the hyponatremia deepens. We think that ascites sodium level can be used for prognostic purposes just like hyponatremia in serum. Further studies are needed on this subject.

Conflicts of interest: The authors declare that there are no conflicts of interest.

Ethics: This study was conducted in accordance with the Declaration of Helsinki. Ethics committee approval was received from Ministry of Health, Ankara Yüksek Ihtisas Hospital (22.02.2018/34). 


\section{REFERENCES}

1. Tsochatzis EA, Bosch J, Burroughs AK. Liver cirrhosis. Lancet 2014;383:1749-61.

2. Peng Y, Qi X, Guo X. Child-Pugh versus MELD score for the assessment of prognosis in liver cirrhosis: A systematic review and meta-analysis of observational studies. Medicine (Baltimore) 2016;95:e2877.

3. Puentes JCP, Rocha H, Nicolau S, Ferrão G. Effectiveness of the MELD/Na score and the Child-Pugh score for the identification of palliative care needs in patients with cirrhosis of the liver. Indian J Palliat Care 2018;24:526-8.

4. Benedeto-Stojanov D, Nagorni A, Bjelaković G, Stojanov D, et al. The model for the end-stage liver disease and Child-Pugh score in predicting prognosis in patients with liver cirrhosis and esophageal variceal bleeding. Vojnosanit Pregl 2009;66:724-8.

5. Biggins SW, Rodriguez HJ, Bacchetti P, et al. Serum sodium predicts mortality in patients listed for liver transplantation. Hepatology 2005;41:32-9.

6. Kim WR, Biggins SW, Kremers WK, et al. Hyponatremia and mortality among patients on the liver-transplant waiting list. N Engl J Med 2008;359:1018-26.

7. Biggins SW, Kim WR, Terrault NA, et al. Evidence-based incorporation of serum sodium concentrationinto MELD. Gastroenterology 2006;130:1652-60.

8. John S, Thuluvath PJ. Hyponatremia in cirrhosis: pathophysiology and management. World J Gastroenterol 2015;21:3197-205.

9. Barakat AA, Metwaly AA, Nasr FM, et al. Impact of hyponatremia on frequency of complications in patients with decompensated liver cirrhosis. Electron Physician 2015;7:1349-58.

10. Angeli $P$, Wong $F$, Watson $H$, Ginès $P$; CAPPS Investigators. Hyponatremia in cirrhosis: results of a patient population survey. Hepatology 2006;44:1535-42.

11. Asrani SK, Kamath PS, Natural history of cirrhosis. Curr Gastroenterol Rep 2013;15:308.

12. Zhu FL, Ling AS, Wei Q, Ma J, Lu G. Tumor markers in serum and ascites in the diagnosis of benign and malignant ascites. Asian Pac J Cancer Prev 2015;16:719-22.

13. Bajaj JS, Wade JB, Sanyal AJ. Spectrum of neurocognitive impairment in cirrhosis: Implications for the assessment of hepatic encephalopathy. Hepatology (Baltimore, Md) 2009;50:2014-21.
14. Rimola A, García-Tsao G, Navasa M, et al. Diagnosis, treatment and prophylaxis of spontaneous bacterial peritonitis: a consensus document. International Ascites Club. J Hepatol 2000;32:142-53.

15. Arroyo $V$, Ginès $P$, Gerbes $A L$, et al. Definition and diagnostic criteria of refractory ascites and hepatorenal syndrome in cirrhosis. International Ascites Club. Hepatology 1996;23:164-76.

16. Elwir S, Rahimi RS. Hepatic encephalopathy: An update on the pathophysiology and therapeutic options. J Clin Transl Hepatol 2017;5:142-51.

17. Bustamante J, Rimola A, Ventura PJ, et al. Prognostic significance of hepatic encephalopathy in patients with cirrhosis. J Hepatol 1999;30:890-5.

18. Iwasa M, Takei Y. Pathophysiology and management of hepatic encephalopathy 2014 update: Ammonia toxicity and hyponatremia. Hepatol Res 2015;45:1155-62.

19. Shah N, Silva RG, Kowalski A, Desai C, Lerma E. Hepatorenal syndrome. Dis Mon 2016;62:364-75.

20. Dever JB, Sheikh MY. Review article: spontaneous bacterial peritonitis--bacteriology, diagnosis, treatment, risk factors and prevention. Aliment Pharmacol Ther 2015;41:1116-31.

21. Samuel D. MELD-Na as a prognostic score for cirrhotic patients: Hyponatremia and ascites are back in the game. J Hepatol 2009;50:836-8.

22. Runyon BA, Montano AA, Akriviadis EA, et al. The serum-ascites albumin gradient is superior to the exudate-transudate concept in the differential diagnosis of ascites. Ann Intern Med 1992;117:21520.

23. Gokturk HS, Demir M, Ozturk NA, et al. The role of ascitic fluid viscosity in the differential diagnosis of ascites. Can J Gastroenterol 2010;24:255-9.

24. Zhu FL, Ling AS, Wei Q, Ma J, Lu G. Tumor markers in serum and ascites in the diagnosis of benign and malignant ascites. Asian Pac J Cancer Prev.2015;16:719-22.

25. Huang LL, Xia HH, Zhu SL. Ascitic fluid analysis in the differential diagnosis of ascites: focus on cirrhotic ascites. J Clin Transl Hepatol 2014;2:58-64. 